\title{
Impact of Coaching With Videos on Self-Efficacy in Nursing Students During the COVID-19 Pandemic
}

\section{Dea Amelia Meilani and Suci Noor Hayati*}

Nursing Study Program, PPNI Stikep School of Nursing, West Java

\section{ORCID}

Suci Noor Hayati: https://orcid.org/0000-0001-6252-481X

Corresponding Author: Suci Noor Hayati; email:

suci.noor@rocketmail.com

Published: 7 February 2022

Publishing services provided by

Knowledge E

(c) Dea Amelia Meilani, Suci Noor Hayati. This article is distributed under the terms of the Commons Attribution License, which permits unrestricted use and redistribution provided that the original author and source are credited.

Selection and Peer-review under the responsibility of the IVCN Conference Committee.

\section{G OPEN ACCESS}

Abstract. The COVID-19 pandemic has changed many aspects of life, especially in the world of education. This coincides with rapid developments in nursing education, including concerning multimedia-based learning processes in the form of videos. Some nursing students are not confident in carrying out patient safety, so a learning method is needed to increase self confidence - one of these is the coaching learning method using videos. This method can also be used to increase self-efficacy and skills in students. This study was conducted to determine the effect of coaching with videos on the self-efficacy of nursing students in carrying out patient safety. The research was a quasi-experimental study with purposive sampling and 60 respondents divided into a control group $(n=30)$ and an intervention group $(n=30)$. Paired sample t-tests and independent sample t-tests were used. According to the results, the coaching method with videos had an effect on self-efficacy in nursing students learning during the COVID-19 pandemic.

Keywords: COVID-19 pandemic, coaching, video, self-efficacy, patient safety, nursing students

\section{Background}

On December 31, 2019, a similar case appeared with unknown pneumonia in Wuhan, China, the case was caused by the corona virus or known as COVID-19 (Corona Virus Desese-2019). The characteristic of this virus is the high speed of spread. The corona virus has also been endemic in Indonesia since early March until now, the impact of the COVID-19 pandemic has changed various aspects of human life. Various policies have been issued by the Indonesian government to reduce the rate of the spread of the corona virus by imposing social distancing, physical distancing to implementing PSBB (large-scale social restrictions) in several areas. The policies issued to limit the spread of COVID-19 have an impact on various fields throughout the world, especially education in Indonesia [8 ].

The COVID-19 outbreak has prompted testing of distance education almost as never before. Online learning has occurred almost all over the world during the COVID-19 
pandemic, so distance learning is a problem, this poses a challenge to all levels of education to keep classes active even if it is done online or online. Lecturers and students as an important element in teaching are required to make an unprecedented large-scale migration, from face-to-face education using conventional learning methods to online education or distance education using technology and electronics [19]

This is supported by rapid developments in the current era of globalization, especially in the field of technology, making humans have the era of the industrial revolution 4.0 which focuses on the world of special education, namely the world of nursing education, which is affected by the era of the industrial revolution 4.0, especially in the electronic-based learning process. . Electronic or digital-based learning has been carried out or practiced into the nursing education curriculum in almost all countries in the world. Electronic-based learning is able to improve online learning effectively to carry out learning even though lecturers and students are in different places and also the flexibility of students towards learning methods, one of which using video media is able to solve the problem of student delays to gain knowledge [17].

Technological developments require the development of good and practical techniques, methods or methods in the teaching and learning process where in the learning process can use a digital or multimedia-based learning media in the learning process [22]. Multimedia in the form of videos shows that this teaching method is feasible and acceptable in improving the quality of teaching. [21]. Learning through video can develop a learning technique so that it gets very maximum results and can facilitate understanding of the material through the senses of sight and also through the senses of hearing, so that it can strengthen students' memory and can also foster confidence in doing a skill.

Besides that, it can also be used in distance learning, students can download it that has been sent via smartphone and can also listen to it or watch it anytime and anywhere, besides that the development of video media in learning can facilitate students to study independently so that when learning in class or also during practice being able to be confident in doing learning. [4]. Changes in learning methods greatly affect the achievement of successful learning objectives. Learning methods are also very much needed in carrying out learning, every learning process is required to use learning methods so that learning can be maximized, also a learning media that can be in the form of video [16].

In this study, the video contained 6 patient safety goals. So, it is very necessary to have an effective learning method in carrying out the implementation of patient safety goals before entering the laboratory or hospital. There are several methods of learning 
that can be applied before entering the laboratory including mentoring methods, role playing (Role-play), demonstrations, field practice, games (games), simulations in the form of videos, and coaching or guidance [6]. In this study, the learning method is in the form of a coaching method.

Coaching is a learning process that provides the widest opportunity for participants, both individually and in groups, to solve their own problems and be accompanied by a facilitator. Coaching is also a process of activities to achieve a work performance where there is someone who accompanies, stimulates and guides to continue to grow so that someone can achieve an expected achievement. Coaching can be said as a learning method that can be developed to improve the quality of nursing resources and increase self-confidence in carrying out an action which will ultimately improve the quality of nursing care provided to patients [20].

From the results of research conducted by [ 13 ] that the application of the coaching method to self-efficacy shows that there is an influence of the coaching method on self-efficacy with a result $(p=0.000$ ) value of less than 0.5 , it is stated that there is an influence of the coaching method on self-efficacy.

The results of the research that has been done [6]. Showing that the coaching guidance method has an effect on increasing self-efficacy in wound care skill competencies, the results are significant $(p=0.004)$. This study concludes that the coaching guidance method to increase self-efficacy in student competencies is more effective.

\section{Research Methods}

The research design used in this study was a quasi-experimental with a Two Group Pretest-Posttest Design approach, namely a research design consisting of two groups, namely an intervention group that received coaching method treatment with videos containing patient safety target procedures, the implementation of the coaching method was carried out in 4 stages with a duration of 30 minutes as much as 4 times. And the control group, namely the group that did not receive the coaching method with video treatment but received the treatment by being given media via power point containing the procedure for patient safety goals.

The population in this study were undergraduate nursing students. The number of samples in this study were 60 respondents. 30 intervention groups and 30 control groups. Sampling in this study using purposive sampling technique that is in accordance with the inclusion criteria. The data collection tool uses a general self-efficacy questionnaire, before being distributed to respondents, validity and reliability tests are carried 
TABLE 1: Description of self efficacy before and after the intervention was given to the control group.

\begin{tabular}{|c|c|c|c|}
\hline \multirow[t]{2}{*}{ Variabel } & \multicolumn{2}{|c|}{ Control Group $(\mathrm{N}=30)$} & \multirow[b]{2}{*}{ Min - Max } \\
\hline & Mean \pm SD & Median & \\
\hline $\begin{array}{l}\text { Total } \\
\text { skor } \\
\text { keselu- } \\
\text { ruhan } \\
\text { self } \\
\text { efficacy }\end{array}$ & & & \\
\hline Pre-test & $29,07 \pm 5,426$ & 27,00 & $19-40$ \\
\hline Post-test & $27,67 \pm 5,441$ & 27,00 & $19-40$ \\
\hline \multicolumn{4}{|l|}{ Magnitudı } \\
\hline Pre-test & $8,63 \pm 1,991$ & 8,00 & $6-12$ \\
\hline Post-test & $8,33 \pm 1,900$ & 8,00 & 6- 12 \\
\hline \multicolumn{4}{|l|}{ Strenght } \\
\hline Pre-test & $14,57 \pm / 1849$ & 13,00 & $10-20$ \\
\hline Post-test & $13,47 \pm / 1623$ & 13,00 & $9-20$ \\
\hline \multicolumn{4}{|l|}{ Generally } \\
\hline Pre-test & $5,87 \pm 1,008$ & 6,00 & $3-8$ \\
\hline Post-test & $5,43 \pm 1,478$ & 6,00 & $3-8$ \\
\hline
\end{tabular}

out first. The statistical test used was the paired sample t-test and independent sample t-test which were used to determine the difference in self-efficacy in nursing student learning before being given an intervention and after being given an intervention in the control group and the intervention group.

\section{Research Result}

\subsection{Description of Self Efficacy Before and After the Intervention was given to the Control Group.}

Based on table 1.1, the results of the pre-test and post-test in the control group using the general self-efficacy instrument consist of 10 questions and are divided into several domains including magnitude, strength, generally. In the results above, there is an average value and standard deviation before being given an intervention or pre test, the overall average value is 29.07 (SD = 5.426), and after being given the intervention or post test the average value is 27.67 ( $S D=5,441$ ). This shows or illustrates that there is no increase in student self-efficacy values before being given the intervention and after being given the intervention in the control group. While in the self-efficacy domain there is an average value and the highest standard deviation in the pretest or before the intervention is given is in the strength domain of 14.57 (SD $=2.849$ ). 
TABLE 2: Description of self efficacy before and after being given an intervention in the intervention group.

\begin{tabular}{|c|c|c|c|}
\hline \multirow[t]{2}{*}{ Variabel } & \multicolumn{2}{|c|}{ Intervention Group $(\mathrm{N}=\mathbf{3 0})$} & \multirow[b]{2}{*}{ Min - Max } \\
\hline & Mean \pm SD & Median & \\
\hline \multicolumn{4}{|c|}{$\begin{array}{l}\text { Total skor keseluruhan self } \\
\text { efficacy }\end{array}$} \\
\hline Pre-test & $26,70 \pm 5,790$ & 26,00 & $19-40$ \\
\hline Post-test & $32,40 \pm 5,969$ & 32,00 & $20-40$ \\
\hline \multicolumn{4}{|c|}{ Magnitude } \\
\hline Pre-test & $7,87 \pm / 1193$ & 8,00 & $3-12$ \\
\hline Post-test & $10,23 \pm 1,305$ & 10,00 & $7-12$ \\
\hline \multicolumn{4}{|l|}{ Strenght } \\
\hline Pre-test & $13,37 \pm / 1953$ & 14,00 & $8-20$ \\
\hline Post-test & $17,37 \pm / 1312$ & 18,00 & $12-20$ \\
\hline \multicolumn{4}{|l|}{ Generally } \\
\hline Pre-test & $5,43 \pm 1,305$ & 5,00 & $3-8$ \\
\hline Post-test & $6,90 \pm 1,155$ & 7,00 & $4-8$ \\
\hline
\end{tabular}

After being given the intervention, there was an average value and the highest standard deviation was in the strength domain of $13.47(\mathrm{SD}=2.623)$. This shows or illustrates that there is no increase in student self-efficacy values before being given an intervention and after being given an intervention in the strength domain. While the lowest domain in the pre-test was in the general domain at $5.87(\mathrm{SD}=1.008)$, and in the post-test there was also the lowest score in the general domain at $5.43(\mathrm{SD}=1.478)$. This shows or illustrates that there is no increase in student self-efficacy scores before and after the intervention is given in the general domain.

\subsection{Description of Self Efficacy Before and After being given an Intervention in the Intervention Group.}

Based on table 1.2 shows the results of the pre-test and post-test in the intervention group using a general self-efficacy instrument consisting of 10 questions and divided into several domains including magnitude, strength, generally. In the results above, there is an average value and standard deviation before being given an intervention or pre-test the overall average value is $26.70(S D=5.790)$, and after being given an intervention or post-test the average value is 32.40 ( $S D=5,969$ ). This shows or illustrates that there is an increase in the value of student self-efficacy before being given an intervention and after being given an intervention. While in the self-efficacy domain there is an average value and the highest standard deviation in the pretest or before the intervention is given is in the strength domain of 13.37 (SD = 2.953). 
TABLE 3: The results of the normality test using the Shapiro Wilk test, obtained the following results

\begin{tabular}{l|l|l|l} 
& & & \multicolumn{2}{l}{ Shapiro wilk } \\
\hline & Statistic & Df & Sig. \\
$\begin{array}{l}\text { Pre- } \\
\text { eksperime }\end{array}$ & 949 & 30 & .157 \\
$\begin{array}{l}\text { Post- } \\
\text { eksperime }\end{array}$ & 956 & 30 & .244 \\
$\begin{array}{l}\text { Pre- } \\
\text { kontrol }\end{array}$ &, 943 & 30 & .112 \\
$\begin{array}{l}\text { Post- } \\
\text { kontrol }\end{array}$ &, 944 & 30 & .115 \\
\hline
\end{tabular}

After being given the intervention, there was an average value and the highest standard deviation was in the strength domain of 17.37 (SD = 2.321). This shows or illustrates that there is an increase in the value of student self-efficacy before being given an intervention and after being given an intervention in the strength domain. While the lowest domain in the pre-test was in the general domain at 5.43 (SD=1.305), and in the post-test there was also the lowest score in the general domain at 6.90 $(S D=1.155)$. This shows or illustrates that there is an increase in student self-efficacy values before being given an intervention and after being given an intervention in the general domain.

\subsection{Normality Test}

The results of the Shapiro Wilk test showed that the pretest-experimental results were $0.157>0.05$ and the posttest-experimental results were $0.244>0.05$, the results of the pretest-control data were $0.112>0.05$ and the post-control was $0.115>0.05$. If seen from the results of the

four data showing $p$ value $>0.05$, the data is normally distributed, the researchers used bivariate analysis to show whether or not there was a significant effect of the video coaching method on self-efficacy in patient safety learning in nursing students by using paired statistical tests. sample t-test and independent sample t-test.

\subsection{The results of the Paired t-test of the Intervention and Control Groups before and after being given the Intervention}

Table 1.4 statistical analysis results of paired sample t-test in the intervention group before and after being given the coaching intervention with video increased significantly from $26.70(S D=5.790)$ to $34.87(S D=4.313)$ with sig. 2 -tailed $=0.000$ Because the value 
TABLE 4: The results of the paired t-test of the intervention and control groups before and after being given the intervention

\begin{tabular}{|c|c|c|c|c|c|}
\hline Variabel & $N$ & $\begin{array}{l}\text { Pre-test (Mean } \pm \\
\text { SD) }\end{array}$ & $\begin{array}{l}\text { Post-test (Mean } \\
\pm \text { SD) }\end{array}$ & $\mathrm{t}$ & Sig (2-tailed) \\
\hline $\begin{array}{l}\text { Intervention } \\
\text { Group }\end{array}$ & 30 & $26,70 \pm 5,790$ & $34,87 \pm 4,313$ & $-6,042$ & 0,000 \\
\hline Control Group & 30 & $29,07 \pm 5,426$ & $27,67 \pm 5,441$ & 1,037 & 0,309 \\
\hline
\end{tabular}

TABLE 5: The results of the independent sample t-test of the intervention and control groups before and after being given the coching method with video

\begin{tabular}{l|l|l|l|l|l} 
Varibel & Mean \pm SD & t & df & $\begin{array}{l}\text { Sig } \\
\text { tailed) }\end{array}$ & $\begin{array}{l}\text { (2- Std. Error } \\
\text { difference }\end{array}$ \\
$\begin{array}{l}\text { Control Group } \\
\text { Intervention } \\
\text { Group }\end{array}$ & $\begin{array}{l}27,67 \pm 5,441 \\
34,87 \pm 4,313\end{array}$ & 5,680 & 58 &, 002 & 1,268 \\
\hline
\end{tabular}

of sig $=0.000$ is smaller than 0.05 then $\mathrm{Ha}$ is accepted, it can also be seen from the $\mathrm{t}$-count value which is -6.042 because the $\mathrm{t}$-count is negative, meaning that there is an increase in pre-test to post-test, which means there is a difference in the average the average between the results of self-efficacy pretest and posttest in the intervention group so that it can be said that there is an effect of using the coaching method with video on self-efficacy in patient safety learning for nursing students.

While the control group did not experience a significant increase with sig $=0.309$ Because the value of sig $=0.309$ is greater than 0.05 then Ho is accepted, it can also be seen from the results of the $t$ count which is 1.037 because the $t$ count is positive it can be said that there is no increase between the pre test to the post test, which means that there is no significant difference between the average scores before and after the intervention. So it can be concluded that when viewed from both the intervention group and the control group, it shows that the intervention group is more effectively used for learning, namely using the coaching method with video.

Table 1.5 results of statistical analysis of independent sample t-test in the control and intervention groups, it is known that the Asymp value. Sig (2-tailed) of $0.002<0.05$, it can be concluded that $\mathrm{Ha}$ is accepted, which means that there is a difference between the control group and the intervention group, and it can be seen also from the mean value that there is a difference in the control group, the mean value is 27.67 ( $S D=5,441$ ) and in the intervention group the mean value was $34,87(S D=4,313)$ which was higher than the control group. Thus it can be concluded that there is a difference in self-efficacy between the intervention group and the control group. Because there is a significant difference, it can be concluded that there is an effect of using the coaching method with video on self-efficacy in nursing learning in the era of the covid-19 pandemic. 


\section{Discussion}

\subsection{Description of Self Efficacy in the Control Group}

Based on the results of research that has been carried out in the control group before and after the intervention was given, the total before the intervention was given was 29.07 and after the intervention was 27.67 so it can be said that the control group before and after the intervention did not experience an increase. Meanwhile, the dimension of self efficacy magnitude (level of difficulty) before the intervention was given was 8.63 and after being given the intervention it was 8.33 so that it can be concluded that there was no increase between before and after the intervention was given. The results of this study are in line with the results of the study [2].

That the magnitude indicator of the control group did not increase. Based on the theory [3] students have a low magnitude meaning that the individual sees himself as only able to do an easy task. While someone who has a high magnitude tends to be able to complete tasks in learning or perform difficult actions. So it is very important for students to have a high magnitude dimension. So it is very important to create an effective learning method to overcome the level of difficulty in learning.

On the dimension of strength before being given the intervention it was .14.57 and after being given the intervention it was 13.47, it can be concluded that the control group before being given the intervention and after being given the intervention did not increase. The results of this study are in line with the results of research by [12] on the indicator of strength after being given the intervention did not experience an increase. Based on Bandura's theory someone who has a low category will easily feel stress in dealing with problems in learning so it is very difficult to achieve a learning goal. Because in this control group learning is only given using power point so that students do not understand the contents of the procedure for implementing patient safety goals so that students' confidence in achieving a patient safety goal learning goal is still lacking. Based on research results [18]. Self-efficacy does not only focus on specific skills possessed by a person, but rather on an assessment of how much confidence one has to do something in accordance with the skills possessed so that it can achieve a desired goal.

In the general domain or the level of confidence a person has in facing a challenge in a situation before being given an intervention is 5.87 while after being given an intervention it is 5.43. Based on the results of this study in line with [2] said that individuals who have confidence in their ability to overcome a challenge in a situation 
that is still at a low score, students never know how to behave in solving unexpected things. when experiencing obstacles in learning. Students who have a low general will tend not to struggle to get an expected achievement.

Description based on self-efficacy in the Intervention GroupBased on the results of research that has been carried out in the intervention group before and after the intervention, the total before the intervention was given was 26.70 and after the intervention was 32.40 , so it can be said that the intervention group before and after the intervention experienced a significant increase. The magnitude dimension also increased before being given an intervention of 7.87 and after being given an intervention it became 10.23 in the intervention group. The results of this study are in line with the results of the study [9]] the magnitude level indicator or difficulty level has increased when doing good learning. difficult usually will not give up and feel lazy.

In line with the theory [3] says that it is very important for students to have a high magnitude dimension because someone who has a high magnitude tends to be able to complete tasks or perform difficult actions. And conversely, if a student has a low magnitude, it means that the individual sees himself as only able to do an easy task. So that the intervention group was given a learning method through videos related to patient safety goals, it really helped students in having difficulty implementing patient safety goals because students had not received material related to patient safety so that students found it difficult to apply patient safety target procedures, with this video learning method students better understand the procedures related to patient safety goals.

The strength dimension before intervention was 13.47 and after intervention was 17.37. The results of this study are in line with the results of research by [12] on the indicator of strength after being given the intervention has increased. Based on Bandura's theory it is very important for students to have a strength dimension (belief in achieving a goal) someone with a high strength dimension or being able to survive in the face of a problem in learning or taking an action. Based on the results of the study [18] concluded that nursing students who have high confidence in their abilities can understand how much confidence they have in carrying out all forms of actions and tasks given so that they can achieve goals in a lesson. So that after being given a learning method through video related to patient safety goals, students feel more confident in their ability to implement patient safety target procedures because in the video it has been explained about carrying out these patient safety goals.

Based on the results of this study in line with [2] said that individuals who have confidence in their ability to overcome a challenge tend to struggle to get an expected 
achievement, and also for someone who has a high general can overcome the obstacles in carrying out and completing tasks in a lesson. This indicator generally refers to the behavior of a person who can face a challenge or difficulty in taking action or learning in various situations.

The results of the analysis of other studies that support this research is the research of [5] concluded that the higher the score, the higher the self-efficacy. Students who have high self-efficacy will tend to choose to be directly involved in doing something in learning, and not view the task as a threat that must be avoided. In addition, students who have high self-efficacy will develop an intrinsic interest and a deep interest in an activity, develop goals and be able to commit to achieving goals. Individuals who have high self-efficacy consider failure to do something in learning as a result of a lack of knowledge, and skills, in carrying out various tasks in learning who have high self-efficacy will perform very well. So it can be concluded that it is very important for students to have high self-efficacy in learning.

Based on the results of research by [11] concluded that it is very important for nursing students to have high self-efficacy because nursing students must be able to improve aspects of cognitive, affective, psychomotor, and nursing science competencies in order to become professional nurses. In addition, nursing students will undergo clinical practice so it is very important to have self-efficacy, nursing students with high selfefficacy will be able to find solutions in deciding the right action to achieve goals. The effect on nursing students who have high self-efficacy can reduce stress, anxiety on students in carrying out an action during learning in the laboratory and clinical practice.

Nursing students who have high self-efficacy can affect the ability to care for patients independently and help students improve their competence and professional skills. This is supported by research by [1] which states that self-efficacy in nursing students will help to have confidence in the competencies they have to accept the challenges given.

The results of research analysis [10] say that someone who has low self-efficacy will cause increased anxiety and avoidance behavior which can worsen the situation this is caused by threats because they feel they do not have the ability to learn so that students feel afraid to take an action. The results of the analysis of other research that support this research is the research of [14] in accordance with Bandura's theory which says that students who have low self-efficacy will have an effect on the learning process so that students will easily feel lazy and high anxiety in learning both in class and in the laboratory. and also have low self-efficacy towards learning so that it can cause a sense of quickly giving up in learning, and feeling afraid to take an action 


\subsection{Differences in self efficacy before and after the intervention was given to the intervention and control groups}

Bivariate analysis describes the significant difference between coaching and video methods on self-efficacy in nursing students. The test used in this study was a paired sample t-test statistic based on the results of the paired sample t-test, the pretest and posttest scores of the intervention group obtained sig. 2 tailed is $0.000<0.05$ which means that there is a significant difference between the mean values before and after the intervention. While in the control group the results obtained sig. 2 tailed is $0.309>$ 0.05 which means that there is no significant difference between before being given the intervention and after being given the intervention. After that, an independent sample t-test was conducted between the intervention group and the control group which showed the results of sig (2-tailed) $0.002<0.05$, which means there is a significant difference, it shows that coaching with video has an effect on self-efficacy.

The results of this study are in line with several previous studies such as the research of [7] which examined coaching on self-efficacy in the results of this study, the results of the statistical test $p=0.000$ showed that there was a difference between the results of the pretest and posttest in the intervention group which could be said to be the effect of coaching on self-efficacy. The results of other studies that support this research are research conducted by [13] which examines coching on self-efficacy. The results of this study obtained statistical test results $p=0.000$ that these results indicate the influence of coaching on self-efficacy so that it can be said the method The coaching is able to increase self-efficacy, coaching is the same in principle, namely providing knowledge and motivation and also being taught skills in increasing self-efficacy.

According to the research results of [20] Providing coaching methods with video can be more effective in increasing self-efficacy because a learning media that can provide the widest opportunity for students, both individually and in groups to solve a problem on their own related to lack of confidence and accompanied by a facilitator. The results of this study are in accordance with the theory put forward by [3] which states that a person's self-efficacy is influenced by several factors, self-efficacy can be obtained, changed, and improved through four factors, one of which is verbal persuasion, namely individuals can help achieve the desired goals. . Individuals who are convinced verbally tend to try harder to achieve a success. The focus on coaching which is included in verbal persuasion includes factors that influence motivation, overcome obstacles, generate solutions, support, and build self-efficacy in taking an action. Verbal persuasion factor is a factor that comes from outside the individual, such as social 
persuasion. Forms of social persuasion can be in the form of praise, encouragement or motivation.

In this study, students were given support in the form of praise and material delivered through videos related to patient safety target procedures whose purpose was to increase student confidence in implementing a patient safety goal. The control group did not experience an increase in self-efficacy due to a lack of approach to respondents because the researcher provided material related to patient safety goals only through power points. While in the treatment group, there were 4 stages which were given material related to patient safety goals through videos, researchers interacted directly with students, students were given repeated motivation so that their self-efficacy increased so that students had strong abilities towards their abilities.

The actions taken were to convince students to continue to apply patient safety goals, both during practice in hospitals and during laboratory practice, and also motivate students to believe in themselves that they can overcome all difficulties in learning in the era of the covid-19 pandemic. at this time. The contents of coaching with videos provided generally include providing information, training students in implementing patient safety goals, helping students overcome obstacles regarding the implementation of patient safety goals, and providing repeated motivation and providing information related to patient safety goals that can support increasing self-efficacy in learning. implementation of patient safety goals during the current eta of the covid-19 pandemic.

Video can be used as an alternative media that can improve students' skills and self-confidence, especially for subject matter that requires skills. Students will be more happy to see videos because watching videos is more directed towards recreation with elements of color, movement, sound so that it can make students stronger in understanding the material. [15] In this study, the video is related to patient safety goals, in the video there are ways to implement patient safety goals.

\section{Conclusion}

The picture of self efficacy in the control group before the intervention was given was 29.07 and after the intervention was 27.67 so it can be said that the control group before and after the intervention did not experience an increase.

The picture of self efficacy in the intervention group before the intervention was given was 26.70 and after the intervention was 32.40 so it can be said that the intervention group before and after the intervention experienced a significant increase. 
The results of the paired sample t-test statistical test showed a significant difference between coaching and video on self-efficacy in patient safety learning in nursing students with a value of 2 -tailed sig $(0.000)<(0.05)$ in the intervention group, and 2-tailed sig. 0.309 in the control group, it can be said that there is no significant difference, while for the results of the independent sample t-test, the results of the 2-tailed sig 0.002 $<0.05$ in the intervention group and the control group can be concluded that the results of hypothesis testing are $\mathrm{Ha}$ accepted, which means there is an effect of the coaching method with video on increasing self-efficacy in learning for nursing students in the era of the covid-19 pandemic.

\section{Suggestion}

It is better to implement the coaching method with video so that it is more effective to do it face-to-face so that researchers interact with respondents much better and clearly, this research is expected to be a research reference and can carry out coaching stages by combining directly in the same session.

\section{References}

[1] Alavi NM. Self efficacy in nursing students. Kashan: Kashan University of Medical Science; 2014.

[2] Amini DA. Gambaran efikasi diri mahasiswa program pendidikan profesi ners fakulta keperawatan universits jember [Doctoral disertation, fakultas keperawatan]. 2020.

[3] Bandura A. Self efficacy, the exercise of control. New York: Freeman and Company; 1997.

[4] Chuang YH, Lai FC, Chang CC, Wan HT. Effect of a skill demonstration video delivered by smartphone on facilitating nursing student's skill competencies and selfconfidence. A randomized controlled trial study. Nurse Education Today. 2018;66:6368. https://doi.org/10.1016/j.nedt.20 18.03.027

[5] Ferdiansyah A, Rohaeti EE, Suherman MM. Gambaran self efficacy mahasiswa terhadap pembelajaran. 2020.

[6] Handiyani D. Pengaruh metode bimbingan coaching dan motivasi terhadap kompetensi rawat luka. Jurnal Citra Keperawatan. 2019;7(2):79-86.

[7] Hariawan H. Pengaruh coching terhadap self efficacy dan perilaku spiritual care pada pasienyang menjalani rawat di rumah sakit [Doctoral dissertation]. Universitas Airlangga; 2018. 
[8] Herliandry LD, Nurhasanah N, Suban ME, Kuswonto H. Pembelajaran pada masa pandemi Covid-19. JTP-Jurnal Teknologi Pendidikan. 2020;22(1):65-70.

[9] Holleb AJ. Principl self efficacy beliefs: What factor matter [Disertasi]. Virginia USA: Polytechnic Institute and State University; 2016.

[10] Hudaepah E. Gambaran tingkat self efficacy pada mahasiswa fakultas keperawatan Universitas Padjajaran. 2019.

[11] Irman O, Wijayanti AR, Rangga YPP. Pelatihan kecerdasan emosional terhadap self efficacy mahasiswa praktik klinik keperawatan gawat darurat. Jurnal Health Sains. 2021;2(6):829-837.

[12] Irwansyah B. Self efficacy mahasiswa prodi PMA dalam pembelajaran kalkus. Logaritma: Jurnal Ilmu-ilmu Pendidikan Sains. 2013;2.

[13] KOA MF. Pengaruh coaching terhadap efikasi diri, perilaku penceghan penularan dan kepatuhan minum obat pada pasien TB penelitian quasy experimental [Doctoral thesis]. Universitas Airlangga; 2019.

[14] Lianto L. Self-efficacy: A briefliterature review. Jurnal Manajemen Motivasi. 2019;15(2):55-61.

[15] Munawaroh S, Pohan VY. Efektifitas media audio visual (video) untuk meningkatkan keterampilan pemeriksaan fisik pada mahasiswa s1 keperawatan muhammadiyah. 2019;4(2).

[16] Nasution MK. Penggunaan metode pembelajaran dalam meningkatkan hasil belajar siswa. Studi Didaktika. 2018;11:9-16.

[17] Nurmagandi B. Penggunaan platform game education dalam pendidikankeperawatan: Kajian literatur. ARTERI: Jurnal IImu Kesehatan. 2019;1(1):8-13.

[18] Stump GSH, Jeneper, Sarah BK. The nursing student self-efficacy scale develoment using item response theory. Nursing Research. 2012;61(3).

[19] Sun L, Tang Y, Zuo W. Coronavirus pushes education online. Nature Materials. 2020;0205. https://doi.org/10.1038/s41563-020-0678-8

[20] Suyasa IGPD, Rismwan M. Pengaruh coaching keperawatan terhadap self efficacy kepatuhan perawat melakukan cuci tangan sesuai prinsip 5 momen 6 langkah. Di ruang rawat inap rumah sakit umum daerah kabupaten klungkung. Jurnal Riset Kesehatan Nasional. 2018;1(1):28-34.

[21] Yang X, Xie RH, Chen S, Yu W, Liao Y, Krewski D, Wen SW. Using video feedback through smartphone instant messaging in fundamental nursing skills teaching. Observational study. JMIR Health and uHealth. 2019;7(9):15386. https://doi.org/10.2196/15386 
[22] Zulfiandra T, Amelia R, Khairi A. Pengembangan game edukasi menggunakan adobe flash pada mata kuliahsistem operasiuntuk mahasiswa pendidikan teknik informatika dan komputer universitas bung hatta. Jurnal Fakultas Keguruan Dan Ilmu Pendidikan. 2020;1(1). 